\section{ANALES DEL INSTITUTO DE INVESTIGACIONES ESTETICAS}

Anales del Instituto de Investigaciones

\section{Estéticas}

ISSN: 0185-1276

iieanales@gmail.com

Instituto de Investigaciones Estéticas

México

Dallal, Alberto

Los ojos del escenario. Escenógrafos de la danza mexicana Anales del Instituto de Investigaciones Estéticas, vol. XXXII, núm. 96, 2010, pp. 55-76

Instituto de Investigaciones Estéticas

Distrito Federal, México

Disponible en: http://www.redalyc.org/articulo.oa?id=36915058003

- Cómo citar el artículo

- Número completo

- Más información del artículo

- Página de la revista en redalyc.org

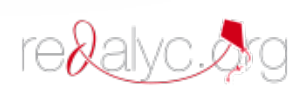

Sistema de Información Científica

Red de Revistas Científicas de América Latina, el Caribe, España y Portugal Proyecto académico sin fines de lucro, desarrollado bajo la iniciativa de acceso abierto 


\author{
ALBERTO DALLAL \\ INSTITUTO DE INVESTIGACIONES ESTÉTICAS, UNAM
}

\title{
Los ojos del escenario Escenógrafos de la danza mexicana
}

A ESCENOGRAFÍA ES EL ARTE DE ARREGLAR y componer plástica, proporcionada y funcionalmente el espacio escénico para que se lleve a cabo una representación. La característica fundamental de una correcta escenografía se vincula con su doble operatividad: de ninguna manera debe interferir; antes bien, debe coadyuvar al desarrollo fluido y eficiente de la experiencia escénica, y al mismo tiempo debe aglutinar sus elementos y completarla. Constituye una parte importante de la esencia dramática del escenario. Su presencia complementaria y a la vez fundamental e indispensable ha hecho al escenógrafo Alejandro Luna "sostener la tesis de que la escenografía no existe..., existe — afirma- el teatro". I

Tanto en las artes del espectáculo más antiguas como en las más recientes, las tareas inherentes a la creación de los espacios donde ha de llevarse a cabo una representación también se consideran escenográficas puesto que perseguían y persiguen asimismo el "arreglo del espacio que corresponde al espectáculo". Por otra parte, el término espectáculo, en la actualidad, debe incluir los eventos que se realizan tanto en el interior como en el exterior de un recinto, así como las prácticas surgidas y aceptadas como nuevos géneros suyos: happenings, conciertos públicos multitudinarios, performances, celebraciones militares y eclesiásticas, torneos, eventos multimedia en el interior y en el exterior, entre otros. En algunos casos podría pensarse en eventos celebrados "alrededor o dentro

I. Vicente Leñero et al., Alejandro Luna. Escenografía, México, El Milagro/Consejo Nacional para la Cultura y las Artes-Instituto Nacional de Bellas Artes/Festival Internacional Cervantino, 200I, p. 3 I. 
de una escenografía", es decir, espectáculos cuyos orígenes se localizan alrededor o dentro de los espacios de una estructura escenográfica. Pueden ubicarse en tal contexto las tradicionales y populares fiestas de I 5 años en México, ${ }^{2}$ las clásicas y estereotipadas bodas de la clase media estadounidense y los desfiles de modas de muchos países del mundo.

Si bien la escenografía debe ser a tal grado funcional que "no se note" e incluso que pase inadvertida a los ojos del espectador no profesional (al que no le interesa recabar información previamente a las representaciones), este arte constituye, en realidad, los verdaderos ojos del escenario en sus dos sentidos posibles: I. la mirada abarcadora que posee la totalidad del espacio escénico en términos de "dominar" internamente hasta el más lejano rincón donde se desarrolla el espectáculo y 2. los ojos "que miran" al espectador, es decir, el espacio compuesto que abarca la totalidad del escenario pero que, al hallarse frente al espectador, se convierte, a su vez, como volumen total, en un observador del espectador o, más bien, del conjunto de espectadores. Y conste que no denominamos a la escenografía la mirada, sino los ojos, porque ante el arreglo total del espacio escénico éste aparece como un bloque que, en conjunto, es el escenario en sí mismo, un volumen que cobra vida al iniciarse la función y lanza sus destellos en dirección del auditorio. ${ }^{3}$ En algún lugar he comparado al espacio escénico con una gran pecera que contiene los acaecimientos del espectáculo.

Como continente y fenómeno complementario de la experiencia de la representación, la escenografía ha existido desde siempre, desde que ancestralmente ocurrió la demarcación de dos espacios específicos: uno para los feligreses y otro para los sacerdotes, uno para los observadores y otro para los semidioses, uno para el público y otro para los actores, uno para los espectadores-participantes y otro para los que representan o danzan en el espacio que les corresponde. ${ }^{4}$ Ya en 1754 , Marmontel se enfrascaba en una polémica relativa a la idoneidad y la coincidencia de los decorados y el vestuario con la naturaleza de la representación. Sobre todo, pugnaba por la posibilidad de que hubiese cam-

2. Alberto Dallal, El “dancing” mexicano, México, Universidad Nacional Autónoma de MéxicoInstituto de Investigaciones Estéticas, 2000, p. I84.

3. "La luz es invisible hasta que incide en la materia y la materia no se ve sino hasta que refleja la luz a nuestros ojos", en Alejandro Luna, "El discurso de la escenografía", México, texto de ingreso a la Academia de Artes, 2007, p. I I.

4. Alberto Dallal, Los elementos de la danza, México, Universidad Nacional Autónoma de México-Fomento Editorial-Danza, 1995, pp. 80-84. 


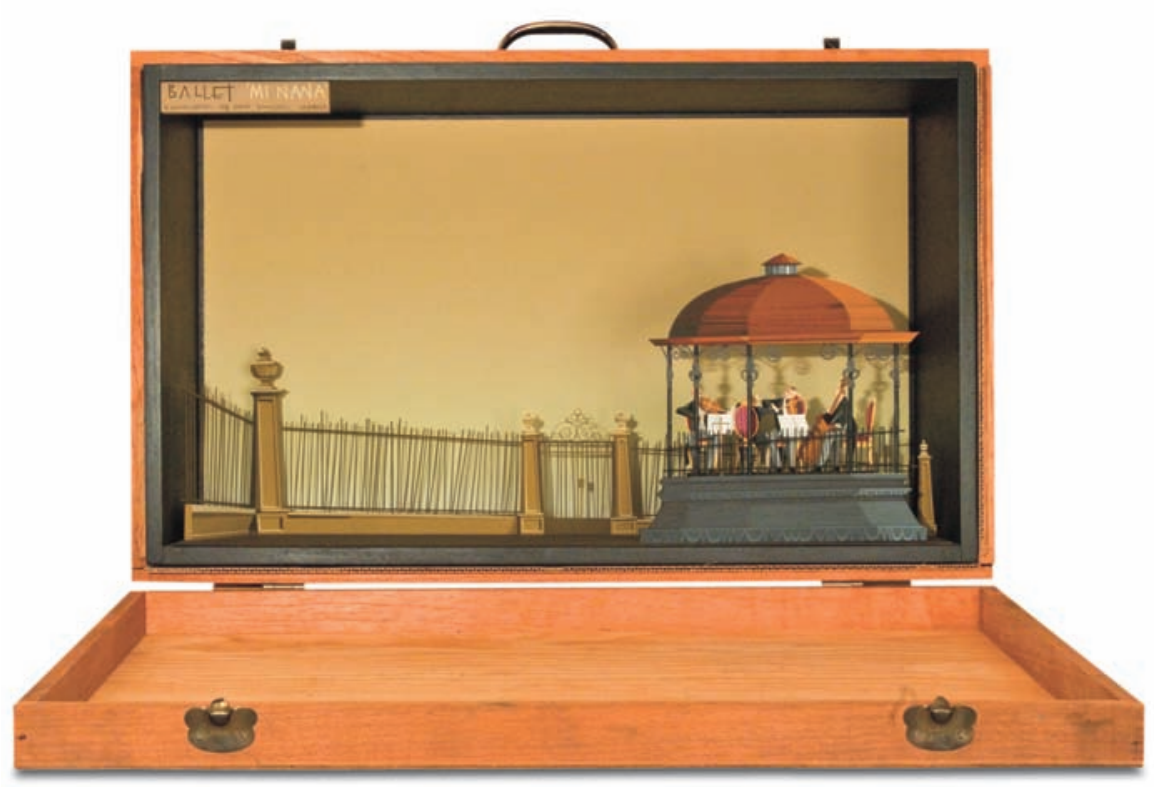

I. Mi nana. Coreografía de Guillermo Keys Arenas, 1960. Escenografía y maqueta: Juan Rangel Hidalgo. Diseño de vestuario: Alejandro Rangel Hidalgo. Foto: Ernesto Peñaloza. Archivo personal de Alberto Dallal.

bios suficientes durante la experiencia escénica para que los autores no se vieran obligados a guardar "la más estricta unidad de lugar" y de situaciones. ${ }^{5}$ Es decir, que en la variedad radica el buen gusto: los autores deberían dar indicaciones, desde el texto creado ex profeso, para que los actores tuviesen, en su espacio, todas las posibles variaciones plásticas y creativas para suscitar sus formas.

Reducida atención se ha prestado al estudio y a la historia de la escenografía en México, tal vez porque la crítica no se considera suficientemente especializada o no ha puesto bastante atención para hacer entrar en el espacio de la creatividad a los "hacedores" de escenografías. O tal vez porque los historiadores y críticos de las artes plásticas sólo consideran secundarias o "aledañas" las incursiones que los pintores, antes del advenimiento de los escenógrafos profesionales, hicieron

5. Mencionado en Marvin Carlson, Theories of the Theatre, Ítaca/Londres, Cornell University Press, I993, p. I50. "Resulta el espacio del escenario fundamental porque dentro de él se lleva a cabo la experiencia teatral y se desarrolla la vitalidad del espectáculo”, en ibidem, p. 409. 
en el plano de las artes del espectáculo, tradición que los pintores europeos sí construyeron aun antes del siglo xx. Con todo, hay varios estudios que reseñan, describen y formulan la historia de la escenografía en México, aspecto que, como otros de las artes plásticas nacionales, siempre ha sido brillante y original. ${ }^{6}$ En México se consideró escenógrafos, durante varios siglos, a los técnicos y diseñadores de los espacios, enseres y telones de los escenarios, pero a partir del siglo $\mathrm{XX}$ acuciosos, especializados y notables escenógrafos mexicanos han trabajado con los directores de teatro y coreógrafos mexicanos durante muchas décadas, sobre todo después del asentamiento del movimiento armado de I910-1920 y la aplicación del programa cultural vasconcelista, en el que se inspiró y apoyó el Movimiento Mexicano de Danza Moderna (1940-1965). ${ }^{7}$

Durante el surgimiento y auge de dicho Movimiento, gran número de pintores mexicanos se incorporó a los trabajos escenográficos, la carrera de escenógrafo se profesionalizó en el país y las tareas técnicas y creativas de los escenógrafos mexicanos se transformaron notablemente. Muchos artistas plásticos coadyuvaron con los coreógrafos del Movimiento a realizar los notables espectáculos de danza de concierto que los ubicaron de manera definitiva en la historia del arte dancístico en el país. A partir de la plena renovación del teatro mexicano impulsada por el surgimiento de Poesía en Voz Alta en la década de los años cincuenta, varios pintores mexicanos contribuyeron al lucimiento escenográfico al ir "más allá de ilustrar simbólicamente los temas fundamentales de la obra o de interpretar pictóricamente la atmósfera en que ocurría. Su desenfadada falta de oficio (escenográfico) rompió reglas obsoletas, anacrónicas y llevó inteligencia al escenario". ${ }^{8}$ Después del Movimiento, a partir de los últimos años de la década de los sesenta, surgieron escenógrafos y diseñadores de gran talento que concentraron su atención y sus trabajos fundamentalmente en el diseño de escenarios de danza, como José Cuervo, Rafael Zamarripa, Kleómenes Stamatiades y Guillermo Barclay, entre otros.

6. Luna, op. cit.; Valeria Prieto y Margarita Suzán Prieto, Julio Prieto. Dormir sólo para soñar, México, Consejo Nacional para la Cultura y las Artes-Instituto Nacional de Bellas Artes/Instituto Mexicano del Seguro Social; Giovanna Recchia, Escenografía mexicana del siglo XX (disquete), y Alejandro Ortiz Bullé Goyri, Teatro y vanguardia en el México posrevolucionario (1920-1940), México, Universidad Autónoma Metropolitana-Azcapotzalco (Serie Humanidades), 2005.

7. Claude Fell, José Vasconcelos. Los años del águila, México, Universidad Nacional Autónoma de México-Instituto de Investigaciones Históricas, I989; Alberto Dallal, La danza en México en el siglo XX, México, Consejo Nacional para la Cultura y las Artes, I994, pp. I4I-I 46.

8. Luna, op. cit., p. Iо. 
2. La vida es sueño. Coreografía conjunta del Ballet Nacional de México. Escenografía de Kleómenes Stamatiades.

Festival Internacional Cervantino, 198I. Foto: Antonio Gutiérrez. Archivo personal de Alberto Dallal.



El Movimiento Mexicano de Danza Moderna auspició los trabajos escenográficos de, entre otros artistas plásticos, Roberto Montenegro, Agustín Lazo, Xavier Lavalle, Miguel Covarrubias y Juan Soriano. El pintor Carlos Mérida incluso contribuyó directamente en 1932 en la fundación de la Escuela Nacional de Danza (fue el primer director de ella), institución que anuncia la renovación de la danza mexicana de concierto; ${ }^{9}$ intervino también personalmente en el diseño y montaje de variadas obras de danza moderna de la época. Asimismo, diseñaron escenografías José Clemente Orozco (La Coronela), Diego Rivera (El cuadrante de la soledad), Gabriel Fernández Ledesma y Rufino Tamayo. Es precisamente durante la última parte del periodo más notable de este Movimiento cuando se hace evidente el surgimiento en el siglo xx del primer escenógrafo de veras profesional en los espectáculos mexicanos y, podríamos afirmar, del primer maestro escenógrafo interesado en "hacer escuela" e impulsar la capacitación de nuevos cuadros para el desarrollo de la escenografía mexicana "hecha y derecha": Julio Prieto (1912-1977), que en 1948 establece

9. Alberto Dallal, La danza contra la muerte, Universidad Nacional Autónoma de MéxicoInstituto de Investigaciones Estéticas, 1993, pp. I09-I I I. 
el Departamento de Producción Teatral en el recién creado Instituto Nacional de Bellas Artes (I946) e instaura la carrera de escenógrafo en la Escuela de Arte Teatral de dicho establecimiento. Separaba así, por primera vez, didácticamente, las instancias generales de apoyo para los trabajos inmediatos del director de escena, por una parte, y las faenas de montaje de las obras (técnicas de producción y diseño escenográfico), por la otra.

En marzo-abril de 1949, se montó en el Palacio de Bellas Artes una Exposición de Escenografía Mexicana Contemporánea. Se mostraban ahí diseños de escenografías y vestuarios que el "recientemente creado Departamento de Producción Teatral del INBA" había confeccionado para las puestas en escena de la cultura oficial. Se exhibieron entonces obras y diseños de Carlos González, Diego Rivera, José Clemente Orozco, Agustín Lazo, Gabriel Fernández Ledesma, Carlos Mérida, Guillermo Meza, Juan Soriano y otros. Eran las escenografías de piezas de danza y teatro como Don Quijote —obra para nińos escrita y dirigida por Salvador Novo-, Antígona, Romeo y Julieta (según el cronista, simultáneamente a ella Fernando Wagner dictó una conferencia entre bambalinas), Orfeo, Judith, Mefistófeles, Sueño de una noche de verano, entre otras. ${ }^{\text {Io }}$

En el presente estudio se refieren las evidentes ligas que, dentro del espectáculo dancísitico, deben guardar el sentido de la coreografía y el diseño y la producción de la creación escenográfica. Los nexos entre escenografía y coreografía se hacen claramente evidentes en los montajes, variados y plenos, del Movimiento Mexicano de Danza Moderna. El término mismo, coreografía, implica de modo directo la separación, por áreas creativas, del espacio escénico. Asimismo, establece y redime el espacio en general, en abstracto (elemento primordial para la realización de cualquier escenografía) como factor básico del arte de la danza. "La escenografía no es sólo una experiencia visual — nos enseña Alejandro Luna-, es la estructura espacial, la estructura física del espectáculo, pero también es el universo visible de la obra, que como un libro requiere de ser leído." II Por otra parte, es necesario tomar en cuenta que la danza es, sin duda, la más antigua de las artes, puesto que su materia prima fundamental es el propio cuerpo humano precisamente en el espacio. Aristóteles consideraba al drama "como elemento de poesía", pero en realidad el "drama

ıo. Henrique González Casanova, "Exposición de escenografía”, México en la Cultura, suplemento de Novedades, io de abril de I949, p. 4.

II. Luna, op. cit., p. II. 


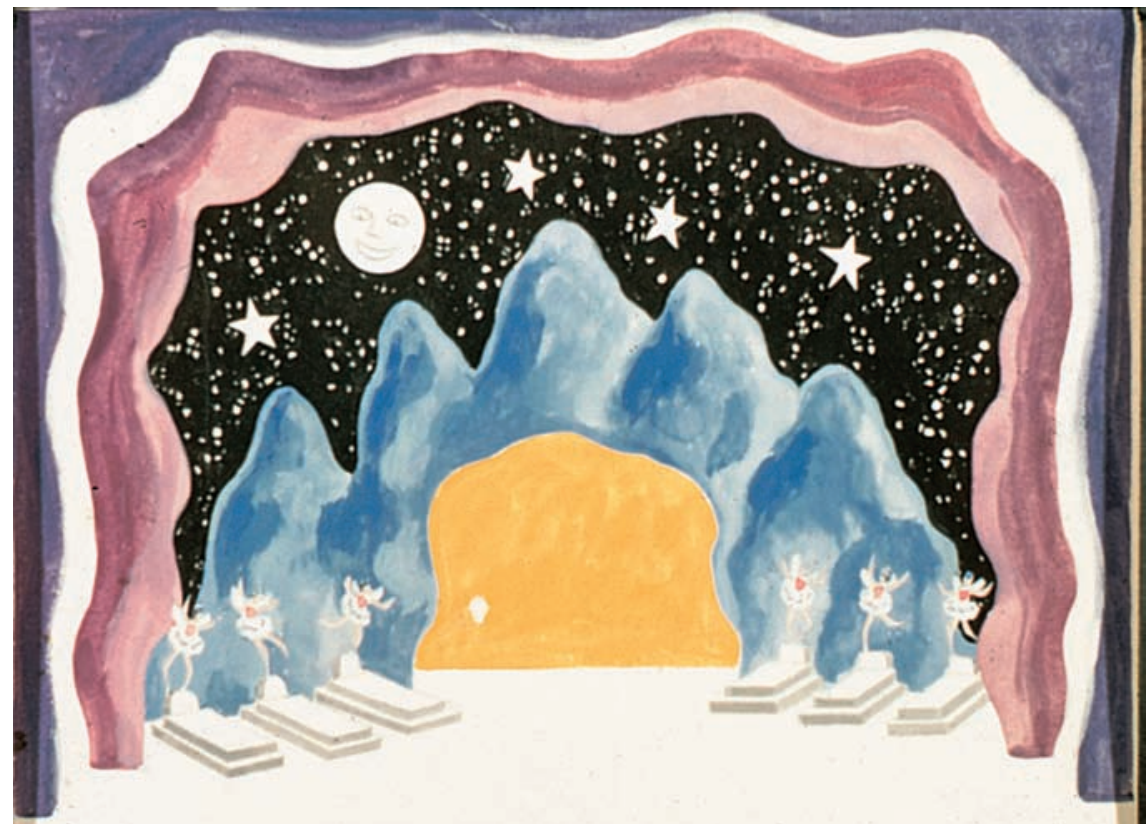

3. Día de difuntos. Coreografía de Ana Mérida. Escenografía de Carlos Mérida, s.f. Archivo personal de Alberto Dallal.

podría haber formado parte de la coreografía", ${ }^{12}$ con lo cual señalaba que términos como drama y texto, acción y verbo pueden muy bien existir en el espacio escénico sin plantearse como elementos exclusivos del lenguaje discursivo (el que utilizamos para hablar y escribir).

Dos aspectos básicos del desarrollo de las artes del espectáculo en el mundo occidental durante el siglo xx transforman la teoría y la práctica del quehacer escenográfico en el mundo: en primer término, las necesarias independencia y profesionalización de la tarea escenográfica (diseño y producción) en los espectáculos fundamentales (teatro, danza, ópera, cabaret, circo y conciertos) y, en segundo término, la incorporación (paulatina al principio, vertiginosa más tarde) de los avances tecnológicos en la entraña misma de la realización de los espectáculos. ${ }^{13}$ Asimismo, deberán considerarse parte de este fenómeno la ampliación

I2. Toni Davis, Escenógrafos, Barcelona, Océano, 200I, p. 7.

I3. "Algunos escenógrafos, como William Dudley y Gunther Schneider-Siemssen, articulan 
y proliferación de géneros dentro de las artes del espectáculo en todo el mundo, incluidos el happening, la instalación, los conciertos de rock, entre otros, aunque tal suceso, es decir, la aparición de nuevos géneros acarreada por motivos tecnológicos, vendría a ser más bien consecuencia de los dos factores antes expuestos.

Resulta por lo menos curioso, por no decir notable, que en México (tal como ocurrió en otros aspectos de la historia de las artes del espectáculo en el país) se instaurara desde 1948 la carrera de diseńador y escenógrafo como una tarea de enseńanza-aprendizaje independiente, como praxis profesional, ya que en otras latitudes tuvieron que producirse variados fenómenos antes de que eso ocurriera. En algunos países europeos hubo de desenvolverse lenta y paulatinamente la profesionalización de los escenógrafos para alcanzar un reconocimiento de este tipo:

El término escenografia — afirma Toni Davis— nació para hacer referencia a la obra del legendario diseñador checo Josef Svoboda y sus magníficos trabajos de diseño de escenarios. Su significado se ha ido ampliando con el tiempo y en la actualidad se aplica tanto al trabajo del diseñador de escenario de una producción como al propio papel que el diseño de escenografía desempeña en la misma. ${ }^{14}$

Naturalmente, la irrupción de la escenografía, del diseño particular del vestuario, de la iluminación y de los espacios escénicos, así como de la producción como ejercicio fundamental de los montajes, implicará en su desarrollo en el siglo xx la irrupción de las grandes producciones al aire libre, de ópera y de rock, así como la inclusión de las complicadas maniobras que en imagen y aparatos de sonido incluyeron otros espectáculos y la misma vida política masificada. Durante el siglo xx, la escenografía, la producción y el diseño de vestuario devinieron profesiones separadas en casi todo el mundo, y ello elevó el nivel de la creatividad escenográfica y sus labores aledañas, como la iluminación, que se convirtieron en ocupaciones especializadas, si no es que en artes por sí mismas. En suma, "ya sea bajo la denominación diseño de escenarios o de escenografía, a finales del siglo xx empezó a considerarse (este ejercicio) en muchos lugares como un estudio superior o como una disciplina artística" Is independiente.

su trabajo con referencias entusiastas hacia los avances tecnológicos, con los que mantienen un compromiso directo"; ibidem, p. 8.

I4. Idem.

15. Ibidem, p. 9. 


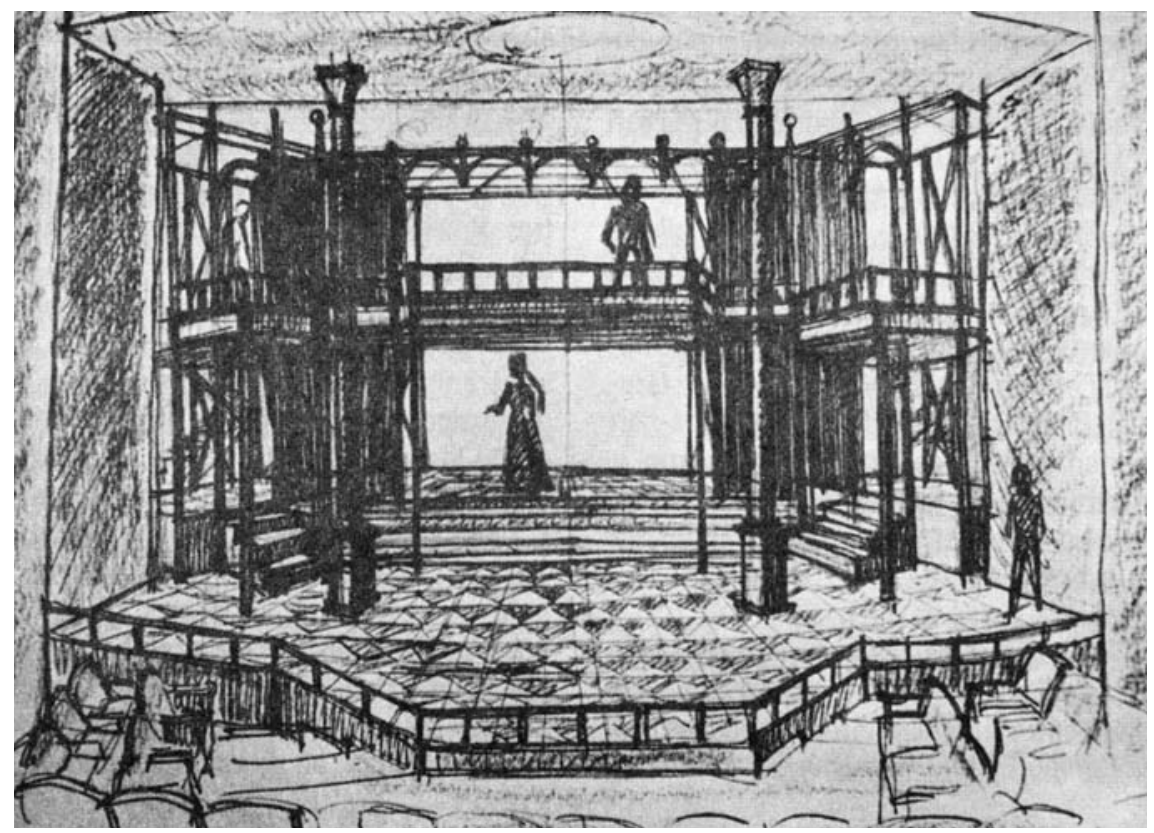

4. Romeo y Julieta. Boceto para escenografía de Julio Prieto, I963. Tomado de Antonio Luna Arroyo (ed.), "Julio Prieto en la historia de la escenografía mundial", sobretiro de la revista Comunidad, febrero de i977, s. p.

Como muchos otros artistas mexicanos, Julio Prieto tuvo que adaptar sus habilidades creativas y técnicas a las circunstancias y oportunidades de la dinámica cultural mexicana. Diseñó más de 3000 escenografías para teatro, ópera y otros espectáculos y echó a andar la constante actualización técnica del enorme monstruo escénico paradigmático, aunque muy operativo y completo, que ha sido siempre el Palacio de Bellas Artes. En estos espacios escénicos enormes, bien dotados, se registraron los momentos clave del Movimiento Mexicano de Danza Moderna. Prieto también fundó y organizó muchos otros centros de arte dramático como los del Seguro Social y el teatro de los Insurgentes. Cumplió cabalmente siempre con la más sencilla de las definiciones de la escenografía: "proveer el ambiente de la expresión dramática". Prieto (puede apreciarse en todas las escenografías y los espacios arquitectónicos que ideó o contribuyó a crear con su asesoría) consideraba fundamental la dimensión humana de los diseños. Durante su ejercicio profesional se hallaban bien delimitadas las diferencias entre los espacios tradicionales del espectáculo y los 
correspondientes a los espectáculos celebrados al aire libre. Eran distintas las concepciones que jugaban y proporcionaban sus reglas en, por así decirlo, lo normal y lo monumental tradicional. La revolución tecnológica del siglo xx, así como la aparición y diseminación masivas de las industrias culturales y electrónicas hicieron mella en la concepción del espacio y en los mismos conceptos de espectáculo. Prieto consideraba esencial la escala humana para responder a los requerimientos tanto de la dirección escénica como de la dramaturgia. El escenógrafo debía mantenerse al servicio de estos dos elementos. Tal dimensión o, mejor, tridimensionalidad humana puede apreciarse en su boceto para la escenografía de Romeo y Julieta de 1963 y en la escenografía de Un hombre contra el tiempo, obra dirigida por Seki Sano en 1963.

El heredero directo de Julio Prieto fue su discípulo Antonio López Mancera (1924-1994), en lo que se refiere no sólo a las tareas de acondicionadormodernizador-actualizador técnico del enorme escenario del Palacio de Bellas Artes, sino también al afán de cumplir, en los diseños de las escenografías, con los cánones de funcionalidad y de obtener los tonos que la naturaleza dramática de cada obra exigiera. López Mancera fue asistente de Julio Prieto de I94I a I95 I y, como él, fue un escenógrafo pulcro, profesionalmente impecable; multiplicó y amplió sus funciones operativas en el diseño de vestuarios y dominó profesional y sesudamente las implicaciones técnicas de la producción y de la escenografía. Es decir, que no sólo era el escenógrafo, sino también el técnico mayor, y asumió además labores de maestro. ${ }^{16}$

Como escenógrafos profesionales, Prieto y López Mancera penetraron en el mundo de la danza centrados en la práctica profesional, a diferencia de los pintores que llevaron a sus diseńos escenográficos de la danza aptitudes, formas y tendencias pictóricas adquiridas de antemano (José Clemente Orozco, Rufino Tamayo y Manuel Rodríguez Lozano, entre otros). Asimismo, López Mancera brindó a los coreógrafos y bailarines, ya como funcionario de Bellas Artes o como maestro de la escuela, facilidades para incursionar en una danza de concierto que había echado a andar con gran impulso y a la que había ampliado sus enormes posibilidades creativas en México desde 1940. Esta circunstancia permitió que la prolongación de la danza moderna, el género danza contemporánea, convocara posteriormente a talentosos escenógrafos jóvenes y

I6. "Antonio López Mancera nos daba una clase a la semana de escenografía en la Facultad de Filosofía y Letras (UNAM) y además nos invitaba a ver los montajes y ensayos de la ópera de Bellas Artes"; idem. 


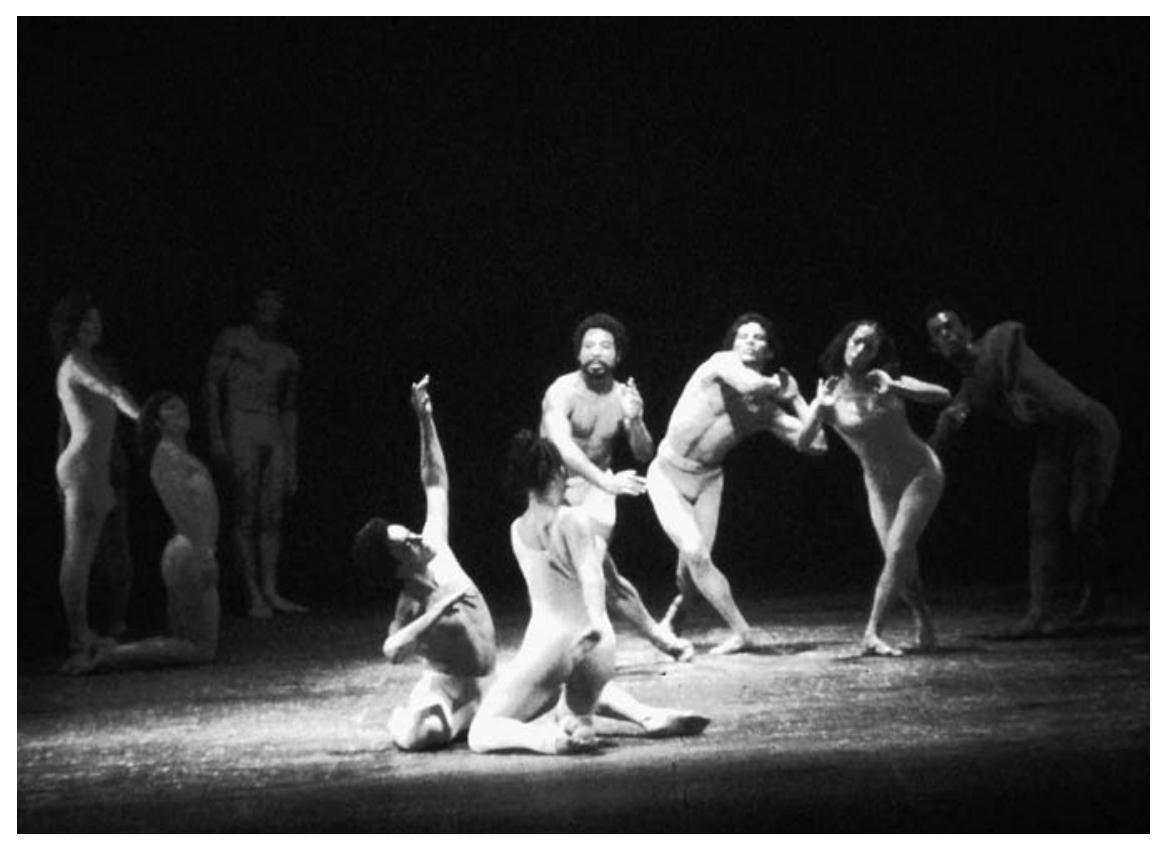

5. Volpone. Escenografía de Gunther Gerszo. Ciudad de México, Palacio de Bellas Artes, s.f. Archivo personal de Alberto Dallal.

los acogiera en sus obras, espacios y escenarios: Guillermo Barclay, José Cuervo, Kleómenes Stamatiades, Jarmila Maserova, entre otros. Así, en la práctica de la danza mexicana, no sólo amplió los conocimientos de los escenógrafos, sino también les permitió, ante la variedad de los temas y las consecuentes características diversas de producción, liberar sus aptitudes creativas. Algunos de ellos, profesionales del diseño, devinieron asimismo escenógrafos de teatro, ópera y otros espectáculos. Mediante el trabajo fecundo, estos creadores se entrenaron de manera completa y profunda y se adaptaron a los requerimientos propios de los coreógrafos, pues, como afirma Ralph Koltai, "no se puede diseñar un escenario para un espectáculo de danza contemporánea sin observar el desarrollo de la coreografía en los ensayos. Tienes que observar ese desarrollo y vivir con él". ${ }^{17}$ Es precisamente en el espectáculo dancístico, en el montaje coreográfico, donde los creadores de la coreografía y de la escenografía trabajan 
en mancuerna: conforman un conjunto de conceptos, estructuras, propuestas, adaptaciones, asentamientos, armonías y soluciones que no tiene parangón con la hechura o realización de otros espectáculos.

Alejandro Luna (nacido en 1939) es el más destacado escenógrafo profesional posterior a Julio Prieto y Antonio López Mancera. Discípulo directo de este último, aprendió "la gramática de la escenografía en el teatro tradicional que viene del siglo XIX, con escenografías pintadas, planas". Luna observó por su parte que, en sus obras, "Julio Prieto [man]tenía su interés en la tridimensionalidad, que también se refleja en los teatros [que construyó] con su hermano Alejandro" para las salas del Instituto Mexicano del Seguro Social y que plasmó en la construcción del teatro de los Insurgentes, de gran influencia entre los arquitectos mexicanos, según los cuales ése "era el teatro moderno y nada más [lo] copiaban". ${ }^{18}$ La enorme sabiduría de Alejandro Luna se plasma en las siguientes palabras, indicadoras del trabajo conjunto con directores de escena y coreógrafos:

lo que hace cada quien depende de muchas circunstancias. He trabajado con directores cuya especialidad es el texto y lo que necesitan es una especie de asesor visual; otros son pintores o arquitectos, como Juan José Gurrola, que necesitan otras cosas. Por eso el papel del escenógrafo es diferente en cada puesta y hay que invertir tiempo en averiguar para qué lo quieren a uno.

$\mathrm{Al}$ ingresar en la Academia de Artes en abril de 2007, Alejandro Luna había realizado el diseño de escenografía e iluminación de 215 obras de teatro, 23 óperas y io coreografías, además de producciones para seis largometrajes y dos teleseries. "Yo entiendo por escenografía — agrega Luna— la organización del espacio para la puesta en escena, es decir, no hay modo de que no haya escenografía. Tan poderoso es un fondo negro que en alguna época se representaba al vacío o un ciclorama que representa al infinito, o el muro de tabique del teatro. Todo significa." ${ }^{19}$

A la sabiduría expresada por Alejandro Luna hay que agregar otro fenómeno: la continuidad del uso de los espacios en el escenario mientras la obra dura (como si el espacio escénico se prolongara en el tiempo), lo cual obliga a

I8. Roberto Perea, "Luna, director desde la escenografía", Proceso, núm. I589, is de abril de 2007.

19. Idem. 




6. Epicentro. Coreografía de Guillermina Bravo. Escenografía de Antonio López Mancera. Ciudad de México, Palacio de Bellas Artes, 1977. Archivo personal de Alberto Dallal.

los escenógrafos a concebirlos de nueva cuenta y a "montarlos" mentalmente, en secuencia, y de una manera distinta. Ming Cho Lee lo admite: "el diseño seminal del escultor Isamu Noguchi para el teatro de danza de Martha Graham expandió mis horizontes escenográficos". ${ }^{20}$ Es decir, se requiere evitar que la escenografía, por sí misma, aislada del hacer coreográfico, pueda propiciar y contener valores de monumentalidad y creatividad que, de manera independiente, sin hallarse al servicio de la coreografía, devenga escultura o pintura divorciada del arte de la danza. Este fenómeno puede apreciarse en algunas buenas fotografías del espacio escénico vacío de participantes. Tal como afirma Toni Davis: "Una escenografía grandiosa puede desviar la atención del público hacia el diseño en sí mismo", ${ }^{21}$ riesgo que los más celebrados y

20. Ming Cho Lee, en Davis, op. cit., p. 40.

2I. Davis, op. cit., p. 7. 
talentosos escenógrafos, como el escultor Noguchi, evitaron siempre en sus diseños para el escenario.

Durante el Movimiento Mexicano de Danza Moderna se expandió notablemente la creatividad de los diseñadores y se impulsó el trabajo conjunto operativo, en algunos casos casi perfecto, entre los coreógrafos y los escenógrafos. Quien haya participado en el estudio de este Movimiento o se haya familiarizado con él situará perfectamente diseńos notables o famosos como el que Leonora Carrington realizó para la danza de Ana Mérida La luna y el venado. Los diseños funcionaron brillantemente para una obra que ofrecía ya aspectos de imaginación semifigurativa en sus acciones coreográficas, alejada de la narración literal que cubrió al Movimiento durante sus primeros años. Y esos mismos alardes de alejamiento de la literalidad los encontramos en los diseños que Juan Soriano realizó para El pájaro y las doncellas, de la misma Ana Mérida, tan temprano como 1947. En 1956, el entonces joven artista Xavier Lavalle ideó para la obra de Olga Cardona Canción de los buenos principios bloques voluminosos y sugerentes de pintura y colores con el fin de que los bailarines pudieran transitar a gusto bajo una sombra plástica que para el público completaba el mensaje o la moraleja comunicada por la coreógrafa mediante su danza.

Por lo visto, algunos diseños que descubrí en algún archivo constituyen, en realidad, ejercicios de bocetos del gisador José Cava que Guillermina Bravo no usó en su obra El demagogo, de 1956, ya que Cava no aparece como titular de los diseños de Xavier Lavalle creados para la obra. Basada en una noticia aparecida en los periódicos de la ciudad de México en aquella época, relativa a la muerte aparentemente accidental de un albañil, Bravo estructuró en El demagogo una coreografía de esencia social (así calificó ella hasta muy recientemente el sentido o el fondo político que soslayan los jóvenes coreógrafos en la actualidad). Gracias a los enormes recursos creativos de la coreógrafa, los personajes de la obra, realistas y a la vez simbólicos, se desenvolvían en una estructura de varios planos que simulaba un conjunto de andamios y vigas propio de un edificio en construcción. En tan variados espacios, los personajes planteaban las situaciones, desarrollaban las acciones y hacían desembocar la trama en un desenlace semejante al de la noticia en torno al albañil. Los diseños definitivos fueron de Xavier Lavalle y, por su matiz de ligereza, resultarían más adecuados y funcionales para la expresividad tenue de la época coreocronológica de Guillermina Bravo, mientras que los diseños de Cava, más realistas, parecen alejarse de los requerimientos y los tonos de la obra. El demagogo aparecía vestido de negro y con levita. Por lo visto las inspiraciones de la coreógrafa 

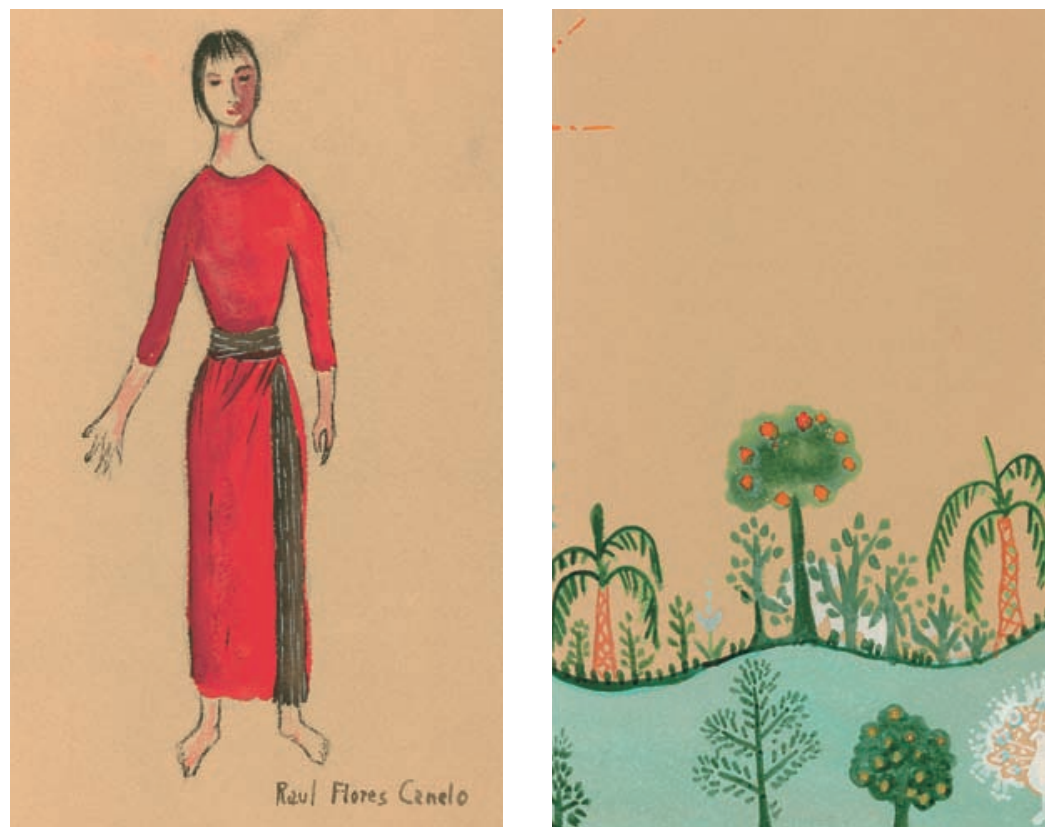

7. Diseños de Raúl Flores Canelo para el Ballet Nacional de México, s.f. Archivo personal de Alberto Dallal.

abandonaban ya, como más tarde lo hicieron definitivamente, los contextos o tejidos realistas y hasta realistas socialistas de algunas de sus obras previas.

Resulta interesante observar los diseńos creados para la coreografía Planos, de Federico Castro, realizada con música de la composición homónima de Silvestre Revueltas, porque la escenografía de Jarmila Maserova responde a la perfección a las intenciones del coreógrafo: utilizar y aprovechar al máximo el plano horizontal del espacio escénico para recrear distintos aspectos de una relación que se expone mediante ciertos brochazos coreográficos donde se entremezclan imágenes difuminadas con narración directa. Esta obra de Castro, el coreógrafo más fiel al Ballet Nacional y a Guillermina Bravo durante 50 ańos, hasta la extinción de la compañía en 2006, contiene elementos notables de una transición asimismo notable. La obra, con música de uno de los compositores que participaron en el Movimiento hasta su muerte — Silvestre Revueltas-, parece combinar los aspectos descriptivos de la danza moderna con las imágenes y las secuencias semifigurativas del nuevo género, la danza contemporá- 
nea. Dentro de la trama, de haberla literariamente, la figura impresionante de Antonia Quiroz es desplazada o, mejor, deslizada por el escenario, como subida en una nave suave de tela blanca, de la que tira hábil y fluidamente Miguel Ángel Añorve. El manejo del espacio escénico del coreógrafo se completa a la perfección con los colores y las texturas y los volúmenes proporcionados por Maserova a melodía, planos escénicos, cuerpos e imágenes. La erección y el desarrollo de la estructura coreográfica se logran mediante una combinación perfecta de espacio, tiempo, propuesta de movimiento, cuerpos, experiencia dancística y mensaje. Este último, desde luego, como puente entre dos épocas, dos lenguajes, dos modalidades de danza de concierto e incluso dos conceptos en la formación y expresividad de los cuerpos de los bailarines: la danza moderna y la danza contemporánea.

Cuando observamos, analizamos y estudiamos los diseños de escenografía y vestuario de antaño, intentamos recuperar un universo complejo que nos revela, además de las tendencias conceptuales de los coreógrafos, la situación y madurez de los montajes de la época y los actuales. Si nos percatamos de las características de una obra de pretensiones y logros monumentales como lo fue $L a$ vida es sueño, compuesta en conjunto por Jaime Blanc, Federico Castro y Luis Arreguín, los tres con la coordinación de Guillermina Bravo, una sola mirada nos indica la sensación múltiple que perseguían los coreógrafos: concentrar en el escenario la vaporosa idea, el conjunto de conceptos y abstracciones que la obra de Pedro Calderón de la Barca manipula en un juego que, a la postre, resulta una interpretación teológica, una búsqueda o, mejor dicho, una persecución de los elementos seminales y religiosos empotrados, por decirlo así, en un andamiaje a la vez expresivo y abstracto. La coreografía es una interpretación, cifrada en varios planos y pisos, de la obra y, curiosamente, intenta lo contrario: alcanzar la volátil textura de los sueños, de la imaginación, de lo inasible o lo inefable mediante trazos por completo gruesos y contundentes, tal como los muy funcionales que aportó el diseño magno de Kleómenes Stamatiades.

Para el Festival de Danza Contemporánea de San Luis Potosí de 2004, Pilar Urreta compuso, mediante una erudita mezcla de imaginativa improvisación y manipulación visual del movimiento, una obra en homenaje a la amistad que su madre, la compositora Alicia Urreta, mantuvo con Federico Silva. La obra adquirió una primera, una segunda, una tercera y hasta una cuarta dimensiones porque correspondía a una estructura inusual: una coreógrafa-bailarina y un escenógrafo-escultor persiguen y a la vez construyen el espacio como un acto de amor a la música y a la persona de Alicia Urreta. La escenografía se combinaba 


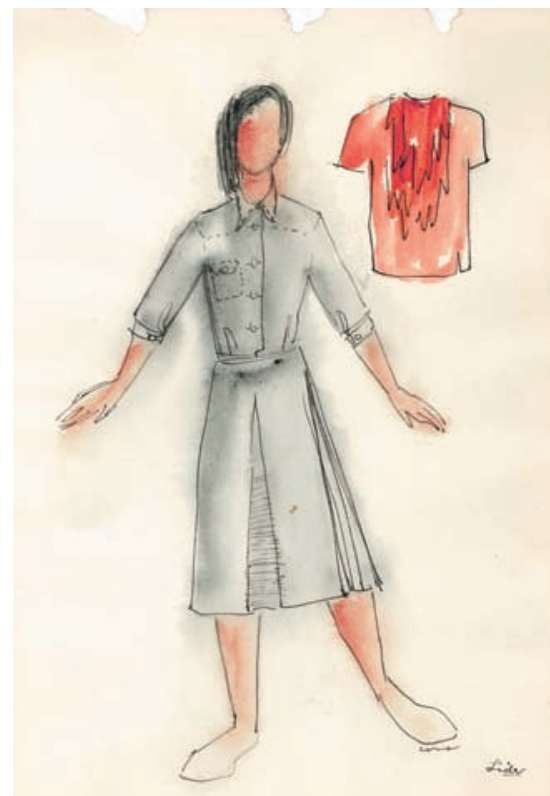

a)

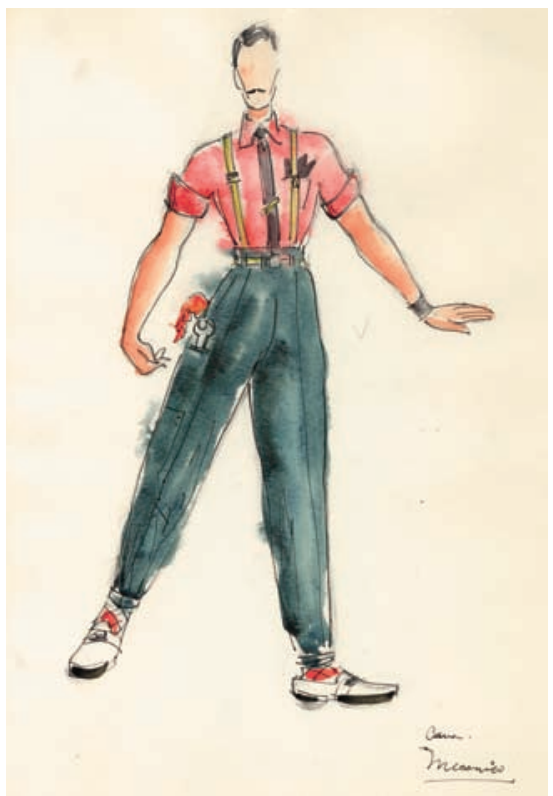

b)

8a) y b). Dibujos de José Cava para el vestuario de El demagogo. Coreografía de Guillermina Bravo, 1956. Archivo personal de Alberto Dallal.

con las subjetividades de la expresividad coreográfica. Los trazos firmes, precisamente definitivos como una escultura, del artista, dieron pie a una especie de apoderamiento de la realidad en dirección de un espacio gris, tibio y lineal que Pilar Urreta unió mediante movimientos contrastados y desplazamientos verticales. A la postre, el espectador se daba perfecta cuenta de que en este caso la coreógrafa se adaptaba al mundo espeso, duro, escultórico de Silva, juego de intersecciones y rimas de piedra propio de un mundo que nos retrotrae no sólo al pasado prehispánico, sino también al espíritu o alma solemne que los mexicanos, aun sin saberlo, llevamos dentro. "Con los brazos abiertos", Silva, a través del cuerpo de la solista, se desplazaba simultáneamente en cuatro dimensiones y establecía un eje de piedra para una sola danza de Pilar Urreta. La bailarina devenía escultura. La obra fue montada y presentada en el Museo Federico Silva de la ciudad de San Luis Potosí.

En años recientes han destacado enormemente las aptitudes de un joven escenógrafo mexicano que ha apetecido la nueva danza mexicana para gozar 
y sufrir en sus trabajos con ella: Jorge Ballina. Nacido en 1968 y arquitecto de formación, escogió desenvolverse en el arte del diseño escenográfico y lo estudió en sus vertientes para teatro y ópera en el Saint Martin's College of Art and Design de Londres. En México, obtuvo las sabias enseñanzas de Alejandro Luna, con quien colaboró en muchas empresas escenográficas hasta alcanzar su plena independencia y su propio y maduro estilo creativo. En 2005 se unió a la también concentrada coreógrafa (con más de I 5 años de trabajo profesional) Alicia Sánchez y con ella elaboró un proyecto que culminó con la puesta en danza de Giselle sí es él en la sala Miguel Covarrubias en 2006. La recreación en danza contemporánea de Giselle era, de por sí, un buen desafío crítico y mediante su escenografía Ballina ofreció paulatinamente las etapas de la aventura: al principio reprodujo un escenario clásico y trasladó en seguida al espectador a las entrańas mismas de un teatro, mediante un juego de espacios que lo hacían penetrar asimismo en un mundo-otro. En la obra aparecían personajes de carne y hueso, bailarines y técnicos que "viven su vida", los avatares del amor, las envidias, los trances de las funciones, los atractivos y rechazos entre ellos mismos, de tal manera operativa y vertiginosa que permitía a los diseños escenográficos convertirse en guía o nave de percances. Ballina dio cabida, junto con el desarrollo de los movimientos creados por la coreógrafa, a un juego de espejos donde el espectador podía acompañar al joven técnico (Giselle es él) en su caída desde las alturas y desembocar en los asépticos espacios de un hospital, en que al fin seguían desempeñándose los bailarines transformistas. Al final, la monumentalidad de las estructuras creadas por Ballina llevaba de la mano al espectador a la revelación de un conjunto de imágenes obsesivas que - según cae en la cuenta el que observa con acuciosidad - volverán a repetirse en la mente del joven técnico, personaje principal de la obra. En los diseños de Giselle sí es él se corroboraba la afirmación del escenógrafo Ming Cho Lee: "Yo creo que nosotros somos personas que creamos un paisaje que puede tener un aspecto moderno o posmoderno o contemporáneo pero que, una vez que termina la representación, deja de tener valor". Jorge Ballina, que también ha incursionado como director de escena, considera que

la integración entre los elementos que conforman la puesta en escena se da cuando hay un verdadero trabajo en equipo entre el coreógrafo, el escenógrafo, el iluminador, el diseñador de vestuario, el compositor o diseñador del sonido, los bailarines, los técnicos y en su caso los músicos (intérpretes). Si el diálogo y la retroalimentación entre los miembros del grupo es efectiva, se pierden los límites entre la labor 
9. Giselle si es él. Coreografía de Alicia Sánchez. Escenografía de Jorge Ballina, 2006. Sala Miguel Covarrubias, unam.

Foto: Guillermo Galindo. Archivo personal de Alberto Dallal.

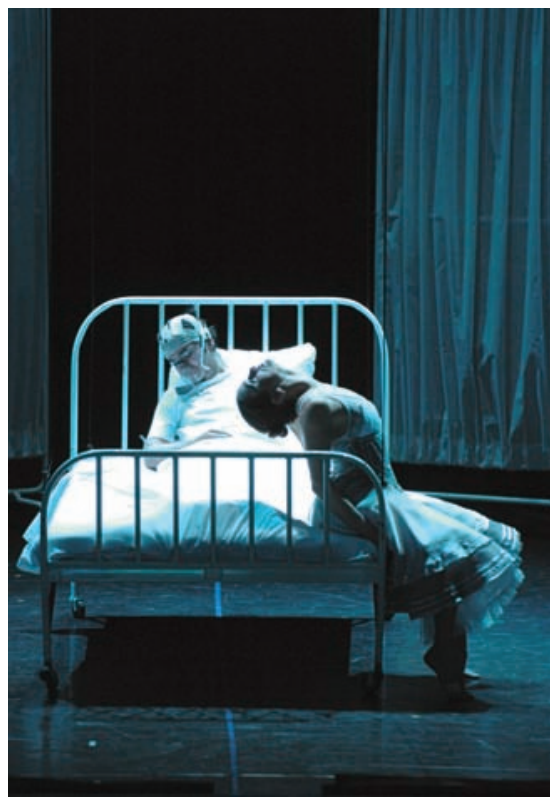

de cada uno. Ya no se sabe de quién fue la idea de qué. Si el espacio se creó para cierto movimiento coreográfico o fue al revés; si las transformaciones de la escenografía y la iluminación se crearon a partir del movimiento de los bailarines o de la música o si estos últimos se adaptaron a los primeros [...] Hay integración cuando no sabemos si lo que sentimos o entendemos de una coreografía nos lo expresa la danza, el espacio, la música o la luz. ${ }^{22}$

En 1977, Guillermina Bravo realizó una de sus obras más perfectas, logradas, elaboradas y complejas: Epicentro. Después de llevar a cabo la consabida investigación alrededor de movimientos y cuerpos, como solía hacerlo, Bravo inició el montaje de un verdadero cúmulo de imágenes en que convergían los más desenvueltos movimientos sensuales y sexuales, los trazos o rasgos de experimentación de una geometría circular, el traslado al escenario de desenvueltas rutinas literales y orgánicas de animales domésticos y, al fin, trazos coreográficos en los que todo este conjunto simultáneo de ambientaciones y espacios, dúos, coros y grupos de bailarines, venía a obedecer las orientaciones de un centro. En

22. Jorge Ballina, "El espacio en la danza y la danza en el espacio", texto inédito, I999. 
tal centro se hallaba, girando sobre su propio eje, Miguel Ángel Añorve, dios, brujo o chamán de estas situaciones superpuestas. Con mucho, Epicentro no sólo fue un alarde de madurez coreográfica. Su estructura expuso asimismo el control depurado, exacto, de los elementos de la danza en el escenario: luz, cuerpos, movimientos, imágenes, sentidos, lapsos. Por último, de manera primordial, los espectadores pudieron percatarse de la culminación de la apertura significativa que había logrado la danza contemporánea para trasladarse a la búsqueda de nuevos lenguajes y territorios: mediante el lenguaje dancístico de los bailarines del Ballet Nacional de México, Bravo generaba un todo semifigurativo que, sin perder su acción comunicativa con los espectadores, creaba, como los pintores impresionistas, certezas pictóricas, pinceladas que, mediante movimientos simultáneos, hacían permanecer sumergidos a los bailarines en un todo de cambiantes colores y tonos, imágenes, curvas y situaciones. Todo ello de la mano de la coreógrafa, quien cerraba el interjuego de volúmenes y espacios, cuerpos y vida, en ese mismo centro en el que había iniciado su exploración por el escenario. Su trabajo con Antonio López Mancera en la búsqueda o, mejor, certeza de la escenografía corroboraba el diálogo preciso que debe establecerse entre diseñador y coreógrafa hasta alcanzar el equilibrio. Tras el estreno de esta obra, López Mancera hubiera armonizado en ideas con el escenógrafo que afirmó: "Yo no sólo creo el diseño del escenario, es decir las máscaras del espectáculo; mi trabajo tiene más que ver con la estructura de la historia en sí misma”.

Trama, narración, historia, situación, conjunto de imágenes... en realidad todo, en danza, converge en una estructura: eso que ocurre, merced a coreógrafos y bailarines, en el tiempo y el espacio, frente a los ojos, absortos y sumisos, asustados o arrobados, de los espectadores. Por ello la danza guarda un intenso vínculo no sólo con lo que en general denominamos cultura, que corresponde o pertenece a un grupo humano, social, sino incluso con cuerpos de hombres y mujeres que poseen, en sí mismos, dentro de sí mismos, una cultura concreta expresada al mismo tiempo que los cuerpos representan el desenvolvimiento del tiempo mitológico y biológico recorrido por la humanidad entera. En estos ojos del escenario que ha conformado y conforma la danza contemporánea mexicana podemos descubrir asimismo, tras lo revelable del trabajo de coreógrafos y bailarines, la sensación plástica de una época, de una vida social, de una tendencia artística. Los ojos del escenario señalan las certezas y a veces sólo las posibilidades estéticas de los "hacedores" de la escena mexicana. Desde la precisa geometría de Carlos Mérida, llena de frisos y colores prehispánicos, podemos transitar en la observación de los diseños escenográficos, hasta las más 


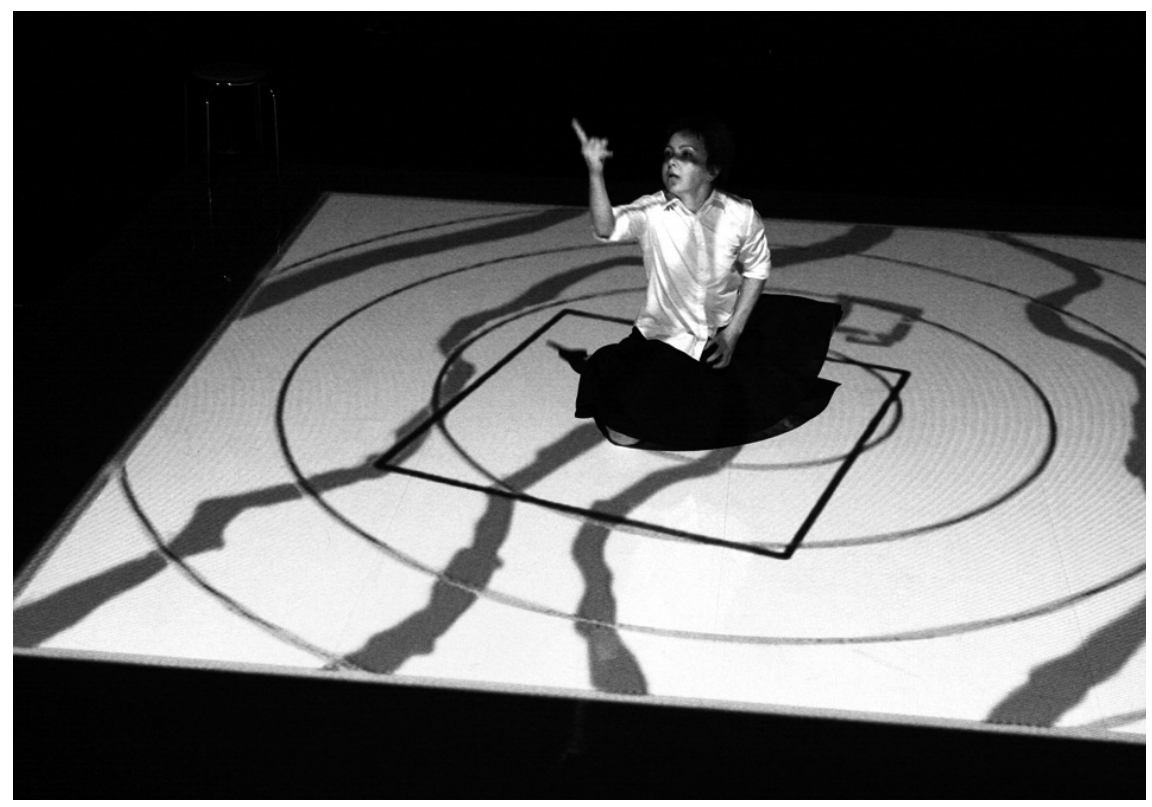

Io. The Hershey Man. Coreografía e interpretación de Gabriela Medina. Compañía La Manga. Diseños e iluminación de Mario Vailla. Nueva York, 2006. Archivo personal de Alberto Dallal.

actuales manipulaciones de los espacios y de los escenarios de la danza mexicana. Las distintas obras y sus escenografías nos hablan asimismo de acuerdos y desavenencias entre coreógrafos y escenógrafos e incluso nos indican cuándo los coreógrafos han obrado por su cuenta y riesgo y sólo llegan a establecer pactos sustanciales con iluminadores, diseñadores de vestuario y técnicos. Pero siempre volveremos a descubrir estructuras y espacio, formas e historias, cultura del cuerpo, conocimiento y sensibilidad: arte.

En De sueños mares, de Cecilia Lugo, una avalancha de arena hace penetrar al espectador en un mundo de viajes y metáforas, de amores imposibles y de seres y cuerpos abandonados (¿tomando el sol o muriendo?) en las arenas ardientes, reales o posibles, del escenario. Constituye una enorme caída de arena que bien puede ser el polvo del tiempo en un botella transparente donde la vida se convierte en cuerpos e imágenes irreales. Los planos ambiguos de la corteza terrestre o los aires vaporosos en que el ser humano deja de ser humano. Todo el interjuego de luces indispensable para saber que la coreógrafa puede prescindir de todo para decir lo que desea decirnos. Las novedosas escenografías de hoy 
nos hacen ver, por otra parte, que el arte de la danza va, como las propuestas artísticas de siempre, en todas las artes, de lo figurativo y lo literal, a la más completa abstracción; de lo obvio y consabido, a la forma del misterio; de las imágenes sin ton ni son, a la más exacta, la más medida estructuración de los trazos coreográficos; de las avalanchas de movimientos e ideas, a los orígenes mismos del cuerpo humano, en sí mismo un mundo, un continente, un conjunto de elementos en los cuales podemos posar los ojos. De lo limitado a lo monumental.

Las secuencias dancísticas van creando siempre el espacio general de una obra, de la misma manera en que el escenógrafo va cubriendo el escenario de trozos de espacios propios para cada secuencia, trozos con nombre propio, real o virtual, en que el bailarín se realiza y se bautiza aprovechando los diseños coreográficos. Espacios empotrados dentro de otros espacios. Espacios difuminados dentro de la gran pecera del escenario.

Las estructuras diseminadas por el espacio escénico son, a su vez, un número infinito de estructuras que van arreglando los silencios y los sonidos, los movimientos y la inmovilidad, la elocuencia y la pausa, la volatilidad y el descanso. Ciertamente, en el escenario no debe sobrar ni faltar nada: todo en el lugar, en el espacio exacto y concreto que le corresponde. Por ello, a veces, no debe sorprender al espectador la ausencia del escenógrafo, pues hay técnicos, iluminadores, bailarines y coreógrafos que se convierten, motu proprio, en los diseñadores de los ojos del escenario.

El escenógrafo, en su trabajo con el coreógrafo, debe percatarse de la invisible trascendencia del espacio escénico, de esa capacidad de la danza para ir construyendo el espacio, haciéndolo histórico, a medida que los bailarines transitan por el escenario. Una obra es en realidad el transcurrir de una estructura en el tiempo desde su origen hasta su extinción. Y, como cada escenógrafo debe hacerse uno con el pensamiento del coreógrafo, con los cuerpos de los bailarines, con los protones de la luz y de las sombras y con todo lo demás, entonces a veces debe asumir su responsabilidad de no ser, de no existir, como lo exigen algunas obras, ya que el coreógrafo, sin más, puede apetecer o sentir como una necesidad el apoderarse, él solo, del espacio escénico. Sí: en las obras de danza, los bailarines pueden muy bien hacer invisibles las escenografías. Deben y pueden lograrlo. Cada escenógrafo, por su parte, parece estar viendo de antemano al espectador, adivinándolo, infiriéndolo, en sintonía con los inventos que son razón de ser del coreógrafo, y en armonía con esos seres a los que reserva pleno respeto y sin los que ninguna obra de danza, ningún diseño escenográfico, ninguna colección de sonidos adquiere vigencia y realidad: los bailarines. \$ 